1. When its thin edges are examined by a strong light, or when very thin slices are inspected in the usual way, it is translucent, transmitting a reddish-brown light, whereas coal is opaque on the thinnest edges.

2. Its fracture, though conchoidal, is perfectly dull in every direction.

3. Its streak is not shining, but quite dull.

4. It changes colour strongly in the streak, which exhibits a distinct pale ochre yellow.

5. It breaks with some difficulty, especially in the cross fracture, and exhibits some degree of elasticity. It is, therefore, not brittle.

6. It ignites very readily, and gives out much light; but when this expires, as it soon does, the remaining mass with great difficulty affords the redness of ignition, as observed in coal under similar circumstances; and it retains its form, though it becomes white by incineration.

It consists of volatile matter from $72 \cdot 5$ to $84 \cdot 1$ per cent. White solid residue, 27.5 to $15.9 \quad \ldots$

It affords a large quantity of fine combustible gas, and also, on distillation, yields much parafine.

It occurs in a bed in the coal formation, associated with shale and ironstone, in the county of Linlithgow, near Bathgate.

The Central Board of Customs of the German Zollverein, assisted by the principal mineralogists of Berlin, have, since this paper was written, decided that the Linlithgowshire mineral is not a coal, and may be imported duty-free, which coal is not.

\title{
2. Notice of the Blind Animals which inhabit the Mammoth Cave of Kentucky. By James Wilson, Esq.
}

The author commenced with a general sketch of the natural character and condition of the great cave, as it is the peculiarities of their local position which constitute the most remarkable feature in the history of the animals by which it is inhabited. The cave descends through the uppermost rocks of the "Barrens" to those which are nearly or quite upon a level with the Ohio. Though called a cave, it is in fact a series of underground galleries, branching from and inosculating with each other in various directions, the 
total length of windings being almost incalculable, and even the direct distance from the entrance to the termination extending many miles. The temperature of these inland galleries is uniformly $59^{\circ}$ of Fahrenheit all the year round; and a current of air is very perceptible near the mouth, proceeding outwards or inwards according as the temperature of the external air is greater or less than that of the subterranean region. The air within is uniformly pure, even exhilarating; and this is attributed in a large measure to the great beds of nitre which disengage oxygen during the formation of nitrate of lime. The general boundaries of the carerns are of limestone.

Of the mammiferous animals described as inhabitants of these caverns, there are two species of bat and one species of rat, the latter being confined to, and characteristic of, the locality. If not blind, its organs of vision are very defective.

Two species of fish were noticed, of one of which, Amblyopsis spelaus of Dekay, specimens were exhibited. It is totally blind, possessing not even rudimentary organs of sight, dissection having shewn that the optic nerve, and other essential parts, are wanting.

Of the crustaceous tribes a blind cray-fish, Astacus pellucidus of Tellkampf, was exhibited. The peduncle of the eye exists, but the actual organ of sight is absent. The observance of this eyeless peduncle had misled some observers into the belief that the creature was not blind.

Various kinds of arachnides, of true insects, and of animalcular species, the majority of them quite blind, were then noticed in the order of their position in systematic arrangements.

The author concluded by referring to the difficulties which beset the theoretic question, as to whether these creatures were blind from their creation, or whether certain species, originally endowed with sight, had wandered by some mischance into those darksome depths, and in the course of ages had lost the organs of a sense, the functions of which they could no longer exercise.

The following Gentleman was duly elected an Ordinary Fellow :-

Grame Reid Mercer, Esq., Ceylon Civil Service.

The following Donations to the Library were announced:Memoirs of the Royal Astronomical Society. Vol. XXI., Parts

\& 2. 4to.-From the Society. 
Proceedings of the American Association for the Advancement of Science. Sixth Meeting, held at Albany (N. Y.) August 1851. 8vo.-From the Association.

Abhandlungen der Königlichen Geselischaft der Wissenschaften zu Göttingen. V. Band. für 1851 \& 1852. 4to.-From the Society.

Mémoires de l'Academie des Sciences de l'Institut de France. Tome XXIII. 4to.-From the Institute.

Abhandlungen der Philosoph.-Philologischen Classe der Königlich Bayerischen Akademie der Wissenschaften. Band XVII., $1^{\text {ste }}$ Abtheil. 4to.-From the Academy.

Nouveaux Mémoires de la Société Helvétique des Sciences Naturelles. Tome XII. 4to.

Mittheilungen der Naturforschen Gesellschaft in Bern. 1851. Nr 195-257. 8vo.

Verhandlungen der Schweizerischen Naturforschenden Gesellschaft bei ihrer 36 sten versammlung in Glarus. 1851. 8vo.From the Society.

Denkschriften der Kaiserlichen Akademie der Wissenschaften. Mathematisch-Naturwissenschaftliche Classe. $\quad B^{d \theta} 4$ \& 5. 4 to.

Sitzungsberichte der Kaiserlichen Akademie der Wissenschaften. Mathematisch-Naturwissenschaftliche Classe. $\mathrm{B}^{\mathrm{de}} 9 \& 10$. 8vo. -From the Academy.

Abhandlungen der Kaiserlich Geologischen Reichsanstalt. Band. I. 1852. Fol.-From the Institute.

Astronomical and Meteorological Observations made at the Royal Observatory, Greenwich, in the year 1851. 4to.-From the Royal Socicty.

The Assurance Magazine and Journal of the Institute of Actuaries. Nos. 12 \& 13. 8vo.-From the Institute.

Journal of the Asiatic Society of Bengal. Edited by the Secretaries. Nos. 230-234. 8vo.-From the Society.

Journal of the Geological Society of Dublin. Vol. V., Part 3. 8ro. -From the Society.

Journal of the Horticultural Society of London. Vol. VIII., Parts 2 \& 3. 8vo.-From the Society.

Journal of the Statistical Society of London. Vol. VI., Parts 1, 2, \& 3. 8vo.-From the Society. 
The Quarterly Journal of the Geological Society. Vol. IX., Parts 2 \& $3 . \quad 8$ vo.-From the Society.

Journal of the Royal Asiatic Scciety of Great Britain and Ireland. Vol. XV., Part 1. 8vo.-From the Society.

The Journal of Agriculture, and the Transactions of the Highland and Agricultural Society of Scotland. No. 41 (N. S.) 8vo. -From the Society.

The Twentieth Annual Report of the Royal Cornwall Polytechnic Society. 1852. 8vo.-From the Society.

The American Journal of Science and Arts. Nos. 44, 45, \& 46. 8vo.-From the Editors.

Transactions of the Pathological Society of London. Vol. IV. 8ro. - From the Society.

Memoirs of the Literary and Philosophical Society of Manchester. 2d Series. Vol. X. 8vo.-From the Society.

Catalogue of the Birds in the Museum of the Asiatic Society of Bengal. By Edward Blyth. 8vo.-From the Society.

Transactions of the American Philosophical Society, held at Philadelphia, for promoting Useful Knowledge. (N. S.) Vol. X., Part 2. 4to.-From the Society.

Observations made at the Magnetical and Metcorological Observatory at Hobart Town, in Van Diemen Island. Printed by order of Her Majesty's Government, under the superintendence of Colonel Edward Sabine. Vol. III. 4to.

Observations made at the Magnetical and Meteorological Observatory at Toronto, in Canada. Printed by order of Her Majesty's Government, under the superintendence of Colonel Edward Sabine. Vol. II. 4to._From Her Majesty's Government.

Observations made at the Magnetical and Meteorological Observatory at Bombay. Printed by order of the Honourable East India Company, under the superintendence of Arthur Bedford Orlebar, M.A. $1845,1846,1847, \& 1848$. 4to.-From the Hon. East India Company.

Abhandlungen der Königlichen Akademie der Wissenschaften zu Berlin. 1852. 4to.

Monatsbericht der Königl. Preuss. Akademie der Wissenschaften zu Berlin. November 1852-Juli 1853. 8vo.-From the Society. 